Jusmal lemiah
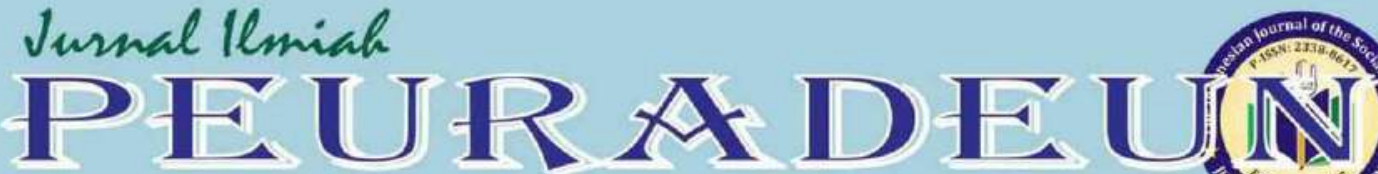

Vol. 8, No. 3, September 2020

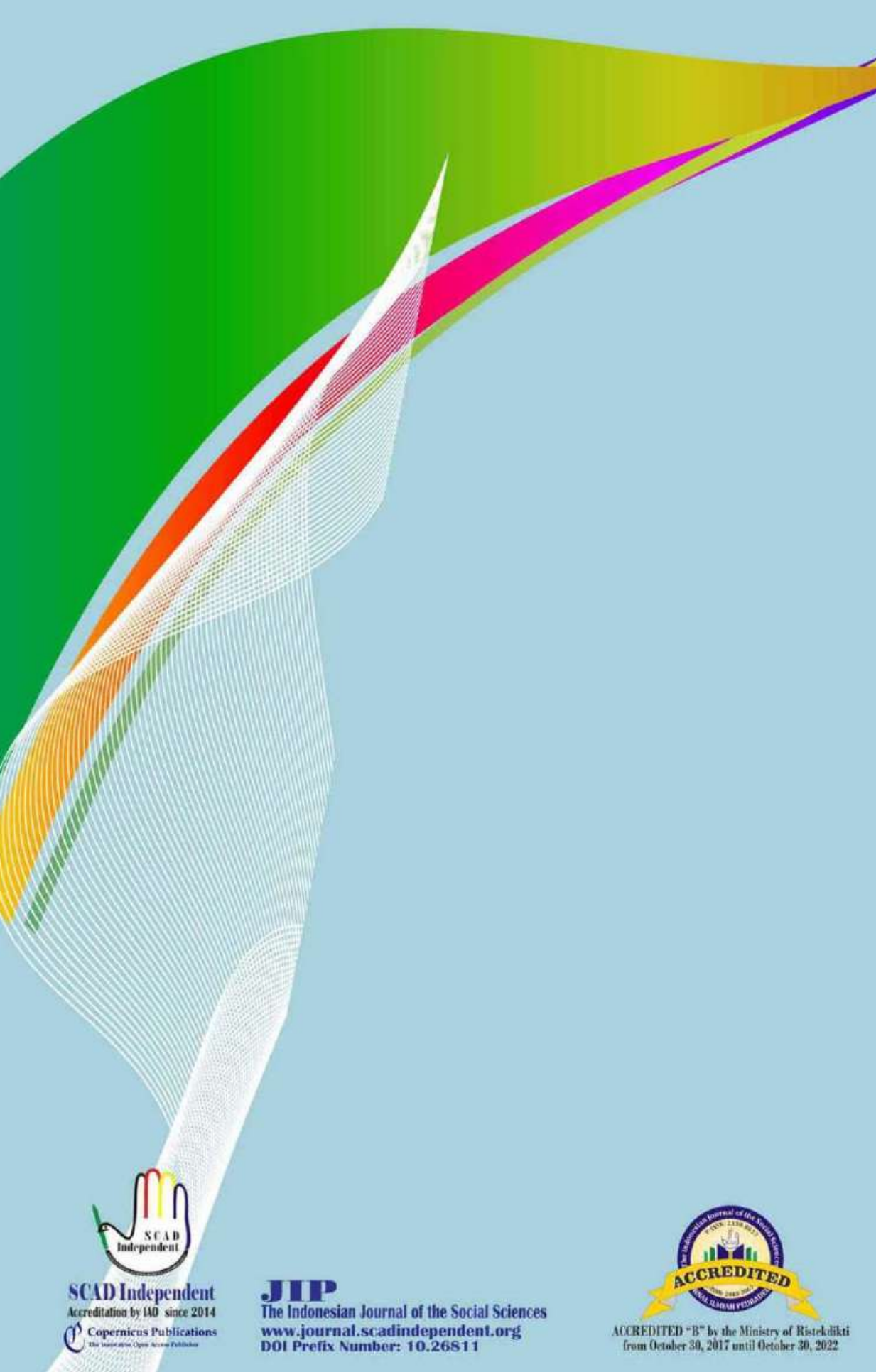

\section{Clarivate Analytics}

Emerging Sources Citation Index Web of Science ${ }^{\mathrm{TM}}$

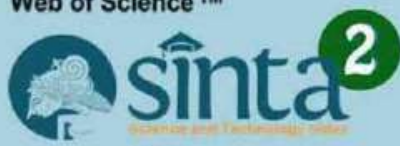

INDEX $\circledast$ COPERNICUS www.journal.scadindependent.org Dot Prefix Number: 10.2681 


\author{
JURNAL ILMIAH PEURADEUN \\ The Indanesian Journal of the Sacial Sciences \\ p-ISSN: 2338-8617/ e-ISSN: 2443-2067
}

www.journal.scadindependent.org

\author{
Vol. 8, No. 3, September 2020
}

Pages: 619-632

\title{
Testing the Views of Children of Terrorists: A Comparative Analysis with Children from Low-Income Families
}

\author{
Husnul Isa Harahap \\ Department of Political Science \\ University of Sumatera Utara, Indonesia
}

\begin{abstract}
Article in Jurnal Ilmiah Peuradeun
Available at : https://journal.scadindependent.org/index.php/jipeuradeun/article/view/435

DOI $\quad:$ http://dx.doi.org/10.26811/peuradeun.v8i3.435
\end{abstract}

\begin{abstract}
How to Cite this Article
APA : Harahap, H. (2020). Testing the Views of Children of Terrorists: A Comparative Analysis with Children from Low-Income Families. Jurnal Ilmiah Peuradeun, 8(3), 619-632. doi:10.26811/peuradeun.v8i3.435
\end{abstract}

Others Visit : https://journal.scadindependent.org/index.php/jipeuradeun

Jurnal Ilmiah Peuradeun (JIP), the Indonesian Journal of the Social Sciences, is a leading peer-reviewed and openaccess journal, which publishes scholarly work, and specializes in the Social Sciences that emphasize contemporary Asian issues with an interdisciplinary and multidisciplinary approach. JIP is published by SCAD Independent and published 3 times of year (January, May, and September) with p-ISSN: 2338-8617 and e-ISSN: 2443-2067. Jurnal Ilmiah Peuradeun has become a CrossRef Member. Therefore, all articles published will have a unique DOI number. JIP has been accredited by the Ministry of Research Technology and Higher Education Republic of Indonesia (SK Dirjen PRP RistekDikti No. 48a/KPT/2017). This accreditation is valid from October 30, 2017 until October 30, 2022.

JIP published by SCAD Independent. All articles published in this journal are protected by copyright, licensed under a CC-BY-SA or an equivalent license as the optimal license for the publication, distribution, use, and reuse of scholarly works. Any views expressed in this publication are the views of the authors and not of the Editorial Board of JIP or SCAD Independent. JIP or SCAD Independent cannot be held responsible for views, opinions and written statements of authors or researchers published in this journal. The publisher shall not be liable for any loss, actions, claims, proceedings, demand, or costs or damages whatsoever or howsoever caused arising directly or indirectly in connection with or arising out of the use of the research material. Authors alone are responsible for the contents of their articles.

JIP indexed/included in Web of Science, MAS, Index Copernicus International, Sinta, Garuda, Moraref, Scilit, Sherpa/Romeo, Google Scholar, OAJI, PKP, Index, Crossref, BASE, ROAD, GIF, Advanced Science Index, JournalTOCs, ISI, SIS, ESJI, SSRN, ResearchGate, Mendeley and others. 


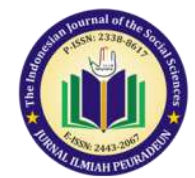 \\ TESTING THE VIEWS OF CHILDREN OF TERRORISTS: A COMPARATIVE ANALYSIS WITH CHILDREN FROM LOW-INCOME FAMILIES

\author{
Husnul Isa Harahap \\ Department of Political Science, University of Sumatera Utara, Indonesia \\ Contributor Email: husnul.harahap@usu.ac.id
}

\begin{abstract}
This research was carried out in the Pondok Pesantren Al-Hidayah. This pesantren is located in Deli Serdang District, North Sumatra Province, Indonesia. It is a boarding school that educates children of terrorists and low-income families. This study aimed to analyze the differences between children of terrorists in comparison to children from low-income families, from the perspective of Indonesian nationalism. The subject is Pancasila: the official, foundational philosophical theory of the Indonesian state. The findings of this study indicated that children from low-income families had a better understanding of Pancasila than children of terrorists. However, this does not mean that all children of terrorists did not understand Pancasila, as there were still those who did comprehend a small amount. Regarding the tendency for violence, this study had found that both children of terrorists and children from low-income families both had a desire to hit if bullied or ridiculed. One prominent difference is that children of terrorists seemed to have different imaginations. They might have visions of heaven as well as sharp objects. The percentage of this occurrence was minuscule, which means this trend did not occur in all children of terrorists. However, this finding indicated that children of terrorists needed special attention.
\end{abstract}

Keywords: Children of Terrorists; Ideologies; Radicalism; Deradicalization; Pancasila. 


\section{A. Introduction}

Terrorism is both a short-term and long-term problem that has not been resolved by the government, especially security forces and other authorities. In early January 2016, Tempo.co released the report "BNPT: 2.7 Million Indonesians Involved in Terrorism." According to Sidratahta Mukhtar, an expert researcher from BNPT, the amount of terrorism is about one percent of the total population of Indonesia. The network is already in Java, Bima, Aceh, and other regions (Hamdi, 2016).

Utilizing data from 2001 to 2017, Kompas.com reported over a thousand suspected terrorist arrests. The data is based on the statement of the Head of the Public Relations Division of the Indonesian Police in Setyo Wasisto in a discussion in Cikini, Central Jakarta on July 3, 2017 (Kuwado, 2017): "It is said that all terrorists were shot dead by Densus 88 , which can be proven. During 2001, Bomb Bali, up to now, a thousand more (suspected terrorists) were arrested and detained... The rest were shot and (died) fighting (Densus 88)... Every incident in Solo involves crippling, fallen offenders. It turns out he was still carrying weapons. The Densus Pass came, and along with it the perpetrators from the bottom and the police. Due to cases like this, the community must maintain awareness, as the implementation of the field is not as easy as turning the palm..." (Kuwado, 2017).

Kompas.com also reported that since 2001, the number of suspected terrorists that died in their homeland was approximately 85 people. A total of 37 of them died on their own accord as a result of suicide bombings. (Kuwado, 2017).

In 2016, the fight against terrorism in Indonesia entered into a new phase. During this time, the precautionary process was causing social impact. One of the social issues regarded the presence of children of either active or former terrorists. The effort to tackle this particular issue was by establishing a school for these children, the Al Hidayah Pesantren Boarding School. The school focuses on deradicalization efforts; however, up until 2018 there haven't been any definitive data announcements about the number of children of terrorists in Indonesia. 
Concern for children of terrorists is vital because they are very vulnerable to being recruited by terrorists. However, the government cannot properly and efficiently deal with the problem of terrorism without the support of those who can help. In the education sector, for example, a university can contribute to the handling of terrorism by conducting research related to issues of terrorism and/or children of terrorists, as well as deradicalization efforts.

Imam Samudra is an example of a case in which a child of a terrorist becomes one himself. What happened to the son of Imam Samudra (the Bali Bomber II)? His son also followed in the footsteps of his father and joined the ranks of terrorists (Sofwan, 2015). This is evidence of how easily terrorism can become multi-generational. The son of Imam Samudra joined the Islamic State in Iraq and Syria (NIIS) and died in 2015 (Radityo, 2015). Based on this fact, it is thought that preventing terrorist regeneration will require eliminating a terrorist's entire family, including the children. If there are 271 terrorist prisoners in prison (Tim Viva, n.d.), then the assumption is that more than 500 children have the potential to become terrorists themselves.

The children of the terrorists became santri (student) at Al Hidayah Boarding House because of the founder of the pesantren, who is also a former prisoner of terrorism. Founders of pesantren are aware that these children are actors who are directly involved when the process of indoctrination of radical ideology is implemented. Thus, they have the potential to become a terrorist, thereby requiring special tactics to be used on the children so they can return to normal. One of the most important tactics occurs through the process of education, called "deradicalization."

In Indonesia, especially in North Sumatra, some children of both active and former terrorists are educated at Al Hidayah Boarding School in Deli Serdang District, North Sumatra Province. The school doesn't only educate children of terrorists, but also children from low-income families. They are incorporated in the Al Hidayah Boarding School run by Khairul Ghazali, a former converted terrorist.

Children from both sides were educated for over a year in general and deradicalization education. The goal was to ensure that children of active 
and former terrorists do not become radical followers in the footsteps of their parents. Moreover, it was also necessary to foster the children from poor families so the boarding school would be seen as being more diverse, so children of terrorists did not feel isolated from their environment.

What are the differences between children of terrorists and children from low-income families regarding their understanding of Pancasila (National Principle and Ideology of the Republic of Indonesia)? What about the tendency for violence? These are two questions that are addressed in this study. There are a few reasons as to why these questions are so important.

First, there is the assumption that children of terrorists tend to be radical. This assumption is based on cases in various countries, including cases occurring in Indonesia. The question is: Is it true that a child of a terrorist has such a tendency? Secondly, children of terrorists have been educated for over a year. However, there has been no evaluation of the process. This study can be a preliminary study of the development of these children.

Third, comparative data on the understanding of Pancasila from children of active and former terrorists, and children from low-income families, will provide a preliminary idea of the differences and similarities of children's perspectives influenced by the background of their experiences. This data reveals whether poverty can affect behavior or a radical mindset.

\section{B. Method}

The method in this research is quantitative descriptive analysis. The total number of students included in the data of students in this boarding school amounted to 20 children. All of them were chosen to be respondents. In its implementation, three santri was ruled out for not participating. Therefore, the santri who became respondents in this study amounted to 17 people. Of the 17, 7 were students who were children of active/former terrorists, and 10 students were children from low-income families. The data collection at the place of the research was conducted by the research assistant. The research instrument is a questionnaire with open and closed questions, as well as different activities, such as drawing, and it usually took about one 
full day for a student to complete. The data was then processed and analyzed by utilizing the quantitative descriptive analysis technique.

Why is this research about children's understanding of Pancasila? Pancasila contains a broad philosophy covering a wide range of topics: the philosophy of peace, humanity, justice, tolerance, and other universal values; it is the unifying ideology of the people of Indonesia; Pancasila has been taught in every elementary school in Indonesia; and lastly, in general, terrorists refuse to recognize Pancasila as a nation's philosophy.

Pancasila is the philosophical basis of the Indonesian state and is comprised of five principles: (1). Belief in the one and only God; (2). A just and civilized community; (3). The unity of Indonesia; (4). Democracy guided by the inner wisdom in the unanimity arising out of deliberations amongst representatives; (5). Social justice for the whole of the people of Indonesia (“National Symbols," 2017).

\section{Literature Review}

According to David H. Gray and Tom Owen Matchin, the issues surrounding children of terrorists are a new phenomenon. Therefore, child terrorism becomes a new challenge for the government in the process of fighting and eliminating terrorism (Gray \& Matchin III Tom Owen, 2008, p. 108). The existence of children of terrorists, as per David H. Gray, is a phenomenon that can be explained from a few different points of view. First, children are susceptible to influence and are easy targets for recruitment. Gray further explains "The LTTE also promises materialistic items or goals to recruit children into their organization" (Gray \& Matchin III Tom Owen, 2008, p. 111). In the case of Sri Lanka, one of their methods is as simple as promising that children will be trained to drive a motorcycle.

Another explanation is that children are easily indoctrinated. The point of indoctrination that Gray makes is to change the behaviors, thought processes, and belief systems of the children. Their new way of thinking would consist of loyalty to the organization, facing the enemy, and a complete change in attitude to achieve the goals of the terroristic group. Gray notes that one of the methods is to repeatedly display 
propaganda videos and promote loyalty oaths. Additionally, it is not uncommon for children to have more abilities and bravery than adults. Their developing minds are quick to absorb new information, and they have a little life experience to develop adequate fear. Also, the presence of children can provide an element of surprise to terrorist eradication efforts. Gray writes, "The deployment of child soldiers in attacks has proved shocking to the Sri Lankan government. The LTTE first deployed child soldiers in early 1990 on an attack at a Sri Lankan army camp in Mankulam" (Gray \& Matchin III Tom Owen, 2008, p. 112). According to Gray, the case is a real-life example that children of terrorists are one of the forces that are often not factored into calculations of risk.

Kumar Ramakrishna, in his article entitled "The Growth of ISIS Extremism in Southeast Asia," sees that ideology plays a role in shaping violent Islamism (Kumar, 2017, p. 8). The ideology is supported by what it calls a "specific masterpiece narrative." One is al-wala wal-bara, or "the unity of all Muslims in connection with non-Muslims." This principle is associated with the condition of the Muslim ummah in the world who are victims of war like in Palestine, Iraq, and Afghanistan. This explanation is based on Christopher Cornell's confession when the FBI interrogated him for planning to attack the president and lawmakers in America. According to Kumar Ramakrishna, this condition is similar to an event in Indonesia whereby the leader of the Jemaah Ansharusy Shariah group (JAS), Abdul Rohim, uses similar narratives.

Various means of media primarily include internet media, especially social media. Social media used includes Facebook, Telegram messenger, and WhatsApp (Moir, 2017, p. 101). Mobile phone technology provides easy access to existing social media. According to Nathaniel L. Moir, in his study entitled "ISIL Radicalization, Recruitment, and Social Media Operation in Indonesia, Malaysia, and the Philippines," it has the potential to elicit even more provoked violent attacks committed by single actors (lone wolf radicalization) (Moir, 2017, p. 102). Thus, the recruiting process of terrorist members can be accomplished indirectly, as well as the transfer of ideology. 
The problem is how to prevent the emergence of radicalism. According to K.H. Hasyim Muzadi, security and repression approaches have proven to have failed with counter-terrorism; many terrorists have been arrested, but since its ideology is still growing, bomb terror continues to occur in Indonesia (Tahir-Ul-Qadri, 2014, p. 17). Wakhid Sugyarto suggests the ideology of terrorism emerges and develops in connection with the ideology of radicalism, through an exclusive religious understanding, people can become satanic. Someone who has believed in fanatic teachings tends to defend his beliefs in every way (Sugyarto, 2015, p. 178). To concur, no attitude is ingrained from birth. No one has been born radical or disciplined, diligent to study, or with hatred towards black people. It's all learned, formed by experience, care, education, or training. Therefore, theoretically, attitude can be changed, reduced, or eliminated through experience, care, education, or training processes that are deliberately made to change attitudes (Sarwono, 2012, p. 131). Thus, there is a correlation between the learning process and the deradicalization process.

\section{Results and Discussion}

Respondents in this study consist of 17 students at Al Hidayah Islamic Boarding School. 41.17 percent are children of active and former terrorists, and 58.82 percent are children from low-income families. If classified by age, then santri (children of terrorists/ex-terrorists) are between 11- and 15-years-old; the majority is 13 years of age, at 42.85 percent (Chart 1$)$. The percentage of other students averages 12.28 percent: all ages from 11 to 15 each amounted to 14.28 percent.

Children from low-income families were between 12- and 16years-old. The largest percentage was with 13-year-olds, at 30 percent. Percentages are different from children of terrorists, who reached 42.85 percent: 12-year-old santri at 20 percent, 14-year-olds at 20 percent, 15year-olds at 20 percent, and 16-year-olds at 10 percent (Chart 1). Thus, 16year-old students from poor families include the least amount, compared with children of terrorists in which there were no 16-year-old respondents. 
Chart 1

Percentage Age of Students at Al Hidayah Islamic Boarding School

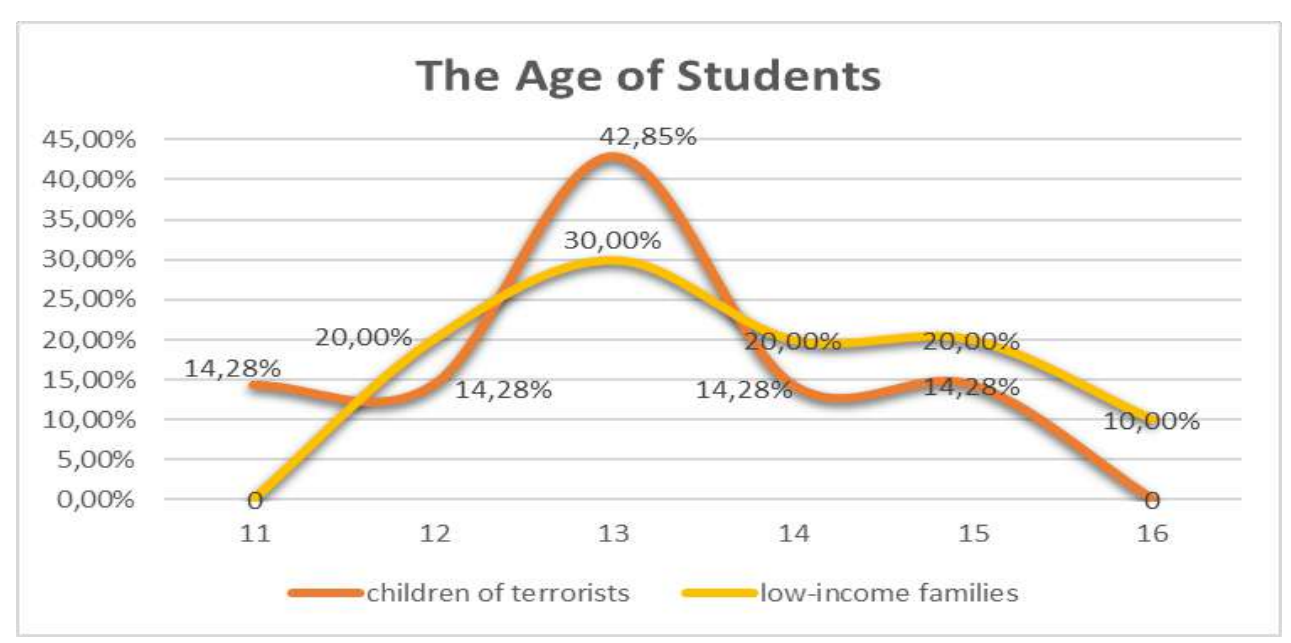

Source: Field research data.

Students who are children of terrorists are boys, as are students who are children from low-income families. It can be said that the students at Pondok Pesantren Al Hidayah are 100 percent male, respectively. There has never been a female student from the origination of this pesantren, nor have there been female teachers.

In general, students are happy to live at this pesantren, especially students who are children of active and former terrorists, who are 100 percent happy to be in Al Hidayah Boarding School. Alternatively, as much as 40 percent of students from low-income families do not view the atmosphere at the boarding school as fun (Chart 2). The biggest contributing factor to their feelings is from missing their parents.

An important aspect to note is that the students do not know that they are objects of deradicalization, which occurs with children of terrorists and those from low-income families. If analyzed further, the only obvious reason as to why this could be is because the students do not understand what deradicalization is. Nevertheless, this is not a very important issue to debate. 


\section{Chart 2}

The Atmosphere at Al Hidayah Islamic Boarding School

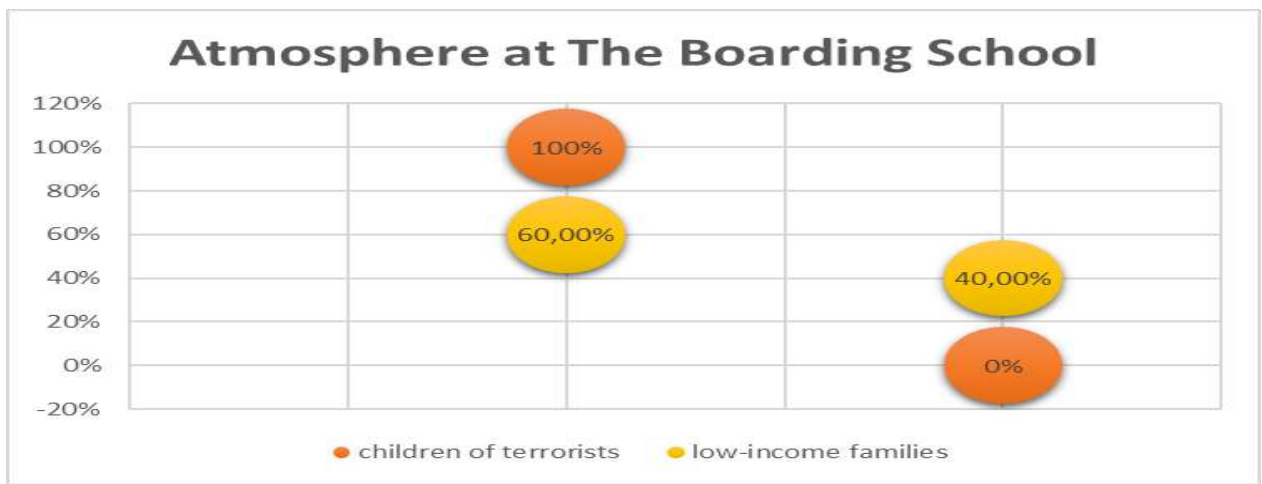

Source: Field research data.

Pancasila is the symbol and ideology of the state of Indonesia and Indonesia Raya is the Indonesian national anthem. As many as 42.85 percent of children of terrorists understand Pancasila and the national anthem, leaving 57.14 of children who lack an understanding (Chart 3). Comparatively, children of poor families who understand Pancasila and the national anthem reach as much as 80 percent, which is a 40 percent increase from children of terrorists.

\section{Chart 3}

The Students Understanding of Pancasila and the National Anthem at Al Hidayah Islamic Boarding School

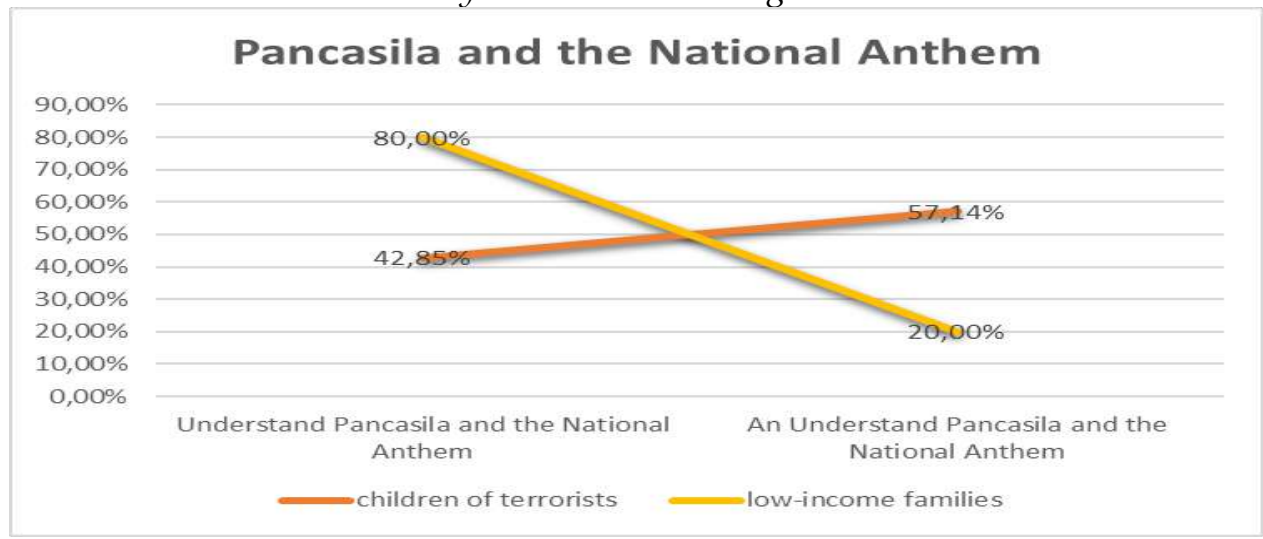

Source: Field research data. 
Another characteristic of children of terrorists is that not many have the desire to become soldiers or policemen, with only 14.28 percent wanting to (Chart 4). Meanwhile, amongst children of poor families, 40 percent want to be soldiers or policemen (Chart 4). It is imperative to ask children what their ideals and hopes are for their lives, as those will illustrate their imagination of life in the future. Goals of becoming a policeman to incarcerate criminals, combat the drug epidemic, and defend the country demonstrate the desire to live meaningful and productive lives.

Chart 4

The Wish of Students at Al Hidayah Islamic Boarding School

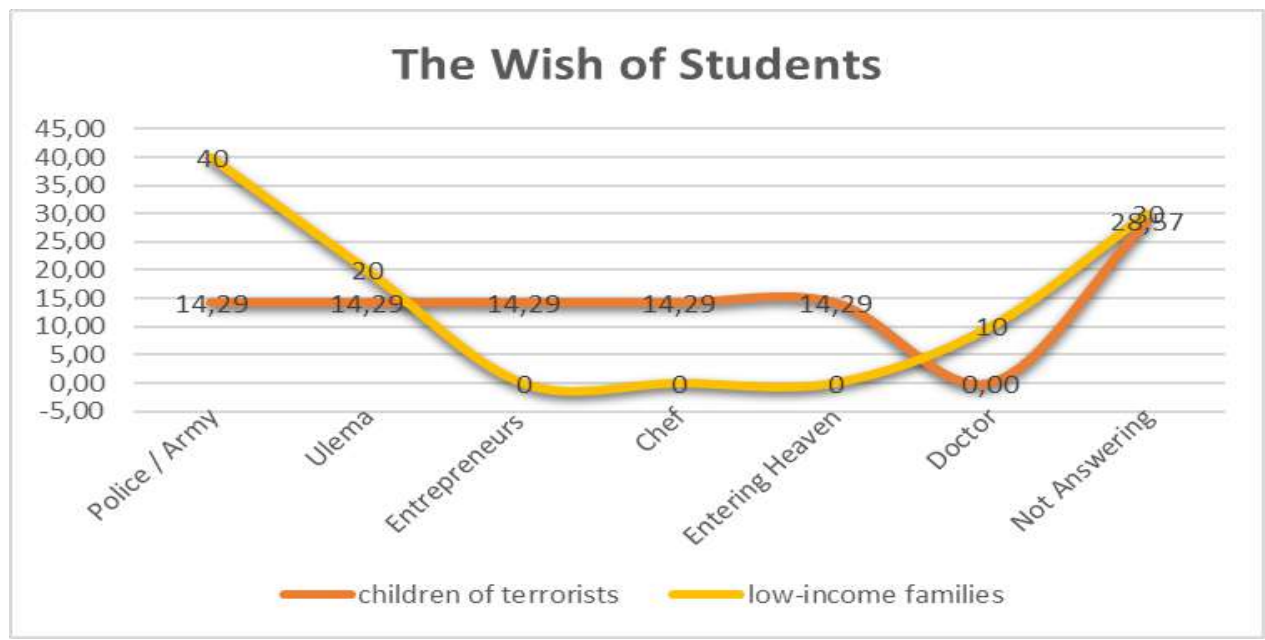

Source: Field research data.

Did the children wish to become ustadz (ulema)? The answer was yes (14.29 and 20 percent). In general, children of terrorists have diverse principles and hopes, for example, wanting to become entrepreneurs and chefs. There are also very ideological beliefs about entering heaven. Students argue that entering heaven is the ultimate objective. This illustrates that reasons for choosing values related to the aspirations of the hereafter are not necessarily the ideals of the rest of the world. Nearly 40 percent of children from low-income families have a different set of goals, which are typically quite common, such as being a doctor (Chart 4). 
Husnul Isa Harahap

Chart 5

The Students Responses When Insulted and Disturbed at Al Hidayah Islamic Boarding School

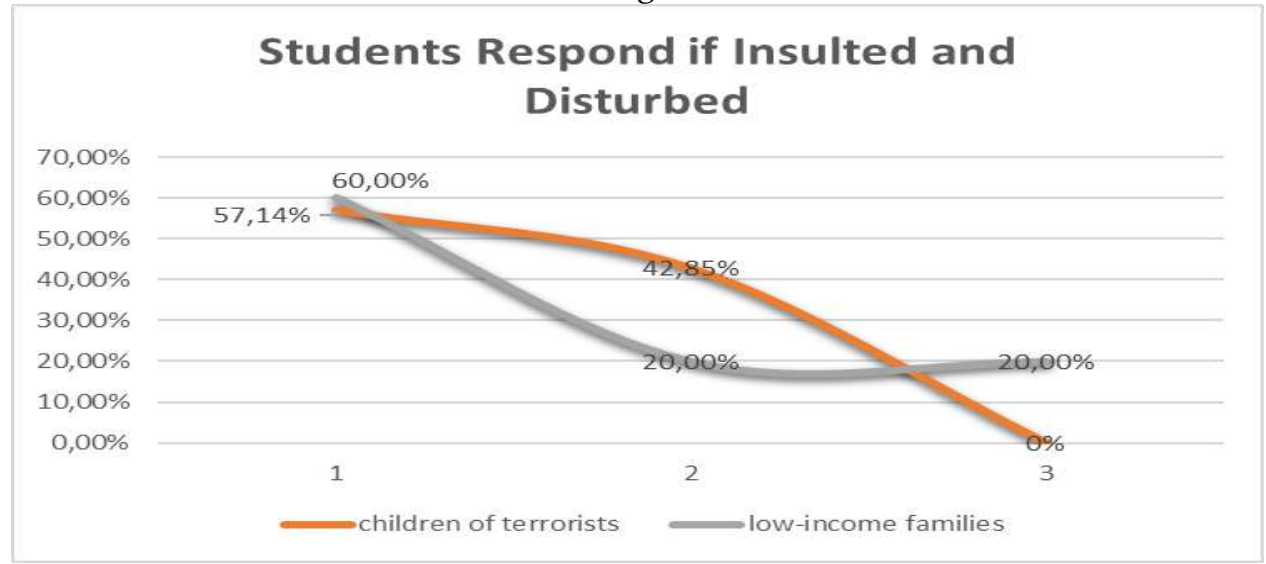

Source: Field research data.

More than half of children of terrorists do not like being insulted; 57.14 percent of them have the will to hit if they are. Besides, 42.85 percent of these children have the desire to hit if they are made fun of by friends, other peers, or their parents. This phenomenon also occurs in children of poor families: 60 percent have the desire to hit, 20 percent do if they feel disturbed, and 20 percent become angry if insulted and disturbed (Chart 5).

\section{Chart 6}

The Imagination of Students at Al Hidayah Islamic Boarding School

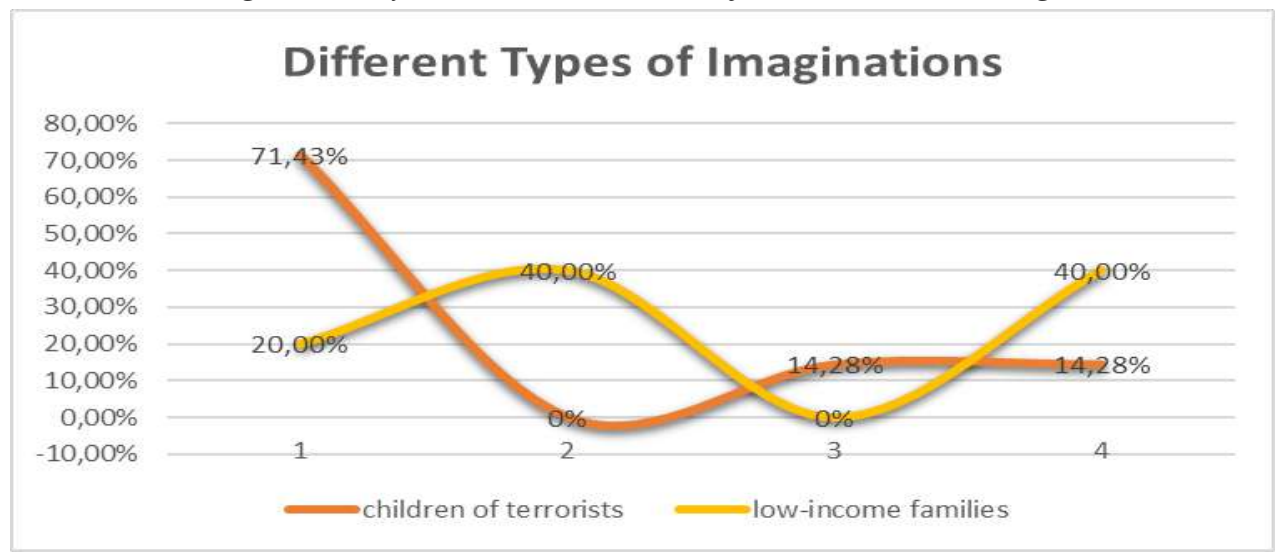

Source: Field research data (draw anything). 
The imagination of children of terrorists is nearly identical to those of other children. 71.43 percent envision having a home one day, which reflects their longing for a family (Chart 6). Meanwhile, among children from low-income families, it's 20 percent. But there are different types of imaginations between the two sets of children. 14.28 percent have visions in the form of sharp objects, which is not found in children of poor families, of which 40 percent generally imagine the landscape (Chart 6).

\section{E. Conclusion}

Both children of active and former terrorists, and children from low-income families, have similarities and differences seen from the standpoint of nationalism. This phenomenon occurs in santri (students) in Al Hidayah Boarding School, Deli Serdang Regency, North Sumatra Province. Children of poor families have a better understanding of Pancasila than children of terrorists. However, this does not mean that all children of terrorists do not understand Pancasila, as there are still some who understand a little. What about the tendency towards violence? The findings of this study indicate that children of terrorists and children of poor families both have a desire to hit if they are bullied or insulted.

There are also differences between children of terrorists and those from poor families, in terms of imagination and ideas for the future. Although there is a need for more in-depth research, it seems that this difference can confirm the assumption that children of terrorists tend to be radical; they strive to reach heaven but also think about using sharp objects. The percentage is not large, which means this trend does not occur in all children of terrorists. On the one side, the findings indicate that they need special attention, and on the other side of this data, in regards to children from lowincome families, it also reveals that poverty has no significant influence on the trend of behaviors or radical mindset among children of poor families. 


\section{Bibliography}

Gray, D. H., \& Matchin III Tom Owen. (2008). Children: The New Face of Terrorism. International NGO Journal, 3(6), 108-114.

Hamdi, I. (2016, January 20). BNPT Sebut Ada 2,7 Juta Orang Indonesia Terlibat Terorisme. Tempo.Co. Retrieved from https://nasional.tempo.co/read/737905/ bnpt-sebutada-27-jutaorang-indonesia-terlibat-terorisme $/$ full\&view $=$ ok

Husen, S., \& Mansor, R. (2018). Parents Involvement in Improving Character of Children Through Mathematics Learning. Jurnal Ilmiah Peuradeun, 6(1), 41-50. doi:10.26811/peuradeun.v6i1.178

Kumar, R. (2017). The Growth of ISIS Extremism in Southeast Asia: Its Ideological and Cognitive Features-and Possible Policy Responses. New England Journal of Public Policy, 29(1), 1-22.

Kuwado, F. J. (2017, June 3). Terduga Teroris Lebih Banyak Ditembak Mati atau Ditangkap Hidup-hidup? Kompas.Com. Retrieved from https://nasional.kompas.com/read/2017/06/03/15030491/terdu ga.teroris.lebih.banyak.ditembak.mati.atau.ditangkap.hiduphidup.

Moir, N. (2017). ISIL Radicalization, Recruitment, and Social Media Operations in Indonesia, Malaysia, and the Philippines. PRISM, 7(1). Retrieved from https://cco.ndu.edu/PRISM-71/Article/1299567/isil-radicalization-recruitment-and-socialmedia-operations-in-indonesia-malays /

Nasor, M., Ngisomuddin, N., \& Alamsyah, Y. (2019). Community Empowerment through Mentari Baitul Mal Wat Tamwil (BMT) to Boost Muslim Family Economy in Kotagajah Central Lampung. Jurnal Ilmiah Peuradeun, 7(3), 569-588. doi:10.26811/ peuradeun.v7i3.440

National Symbols [Consulate Offices]. (2017). Retrieved from The Embassy of the Republic of Indonesia website: https://www.embassyofindonesia.org/index.php/nationalsymbols/

Radityo, M. (2015, Kamis, Oktober 18:32). Gabung ISIS, anak Imam Samudra tewas di Suriah. Merdeka.Com. Retrieved from 
https://www.merdeka.com/dunia/gabung-isis-anak-imamsamudra-tewas-di-suriah.html

Sarwono, S. W. (2012). Terorisme di Indonesia. Tanggerang: PT Pustaka Alvabet.

Sofwan, R. (2015, October 30). Kapolri: Anak Imam Samudra Punya Jaringan Berbahaya. CNN Indonesia.Com. Retrieved from https://www.cnnindonesia.com/nasional/20151030112459-1288403/kapolri-anak-imam-samudra-punya-jaringan-berbahaya

Sugyarto, W. (Ed.). (2015). Profil Keagamaan Terpidana Terorisme di Indonesia. Jakarta: Kementerian Agama RI, Badan Litbang dan Diklat Puslitbang Kehidupan Keagamaan.

Sulaiman, A., Masrukin, M., \& Suswanto, B. (2019). The Implementation of Community Empowerment Model as a Harmonization in the Village Traumatized by Terrorism Case. Jurnal Ilmiah Peuradeun, 7(1), 59-80. doi:10.26811/peuradeun.v7i1.257

Tahir-Ul-Qadri, M. (2014). Fatwa tentang Terorisme dan Bom Bunuh Diri. Jakarta: Lembaga Penelitian dan Pengkajian Islam.

Tim Viva. (n.d.). Berapa Jumlah Napi Teroris di Indonesia. Viva.Co.Id. Retrieved from https://www.viva.co.id/berita/nasional/937613berapa-jumlah-napi-teroris-di-indonesia 